\title{
Oxford Nanopore Sequencing
}

National Cancer Institute

\section{Source}

National Cancer Institute. Oxford Nanopore Sequencing. NCI Thesaurus. Code C146818.

A proprietary next-generation DNA sequencing technology from Oxford Nanopore

Technologies that can directly identify and sequence a DNA molecule as it passes

through a nanopore, driven by electrophoresis. 